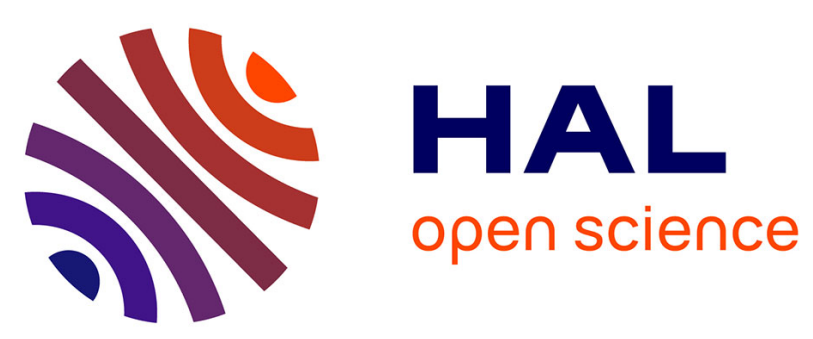

\title{
Earthworms (Millsonia anomala, Megascolecidae) do not increase rice growth through enhanced nitrogen mineralization
}

\author{
Manuel Blouin, Sébastien Barot, Patrick Lavelle
}

\section{- To cite this version:}

Manuel Blouin, Sébastien Barot, Patrick Lavelle. Earthworms (Millsonia anomala, Megascolecidae) do not increase rice growth through enhanced nitrogen mineralization. Soil Biology and Biochemistry, 2006, 38, pp.2063-2068. 10.1016/j.soilbio.2005.12.023 . bioemco-00448744

\section{HAL Id: bioemco-00448744 \\ https://hal-bioemco.ccsd.cnrs.fr/bioemco-00448744}

Submitted on 20 Jan 2010

HAL is a multi-disciplinary open access archive for the deposit and dissemination of scientific research documents, whether they are published or not. The documents may come from teaching and research institutions in France or abroad, or from public or private research centers.
L'archive ouverte pluridisciplinaire HAL, est destinée au dépôt et à la diffusion de documents scientifiques de niveau recherche, publiés ou non, émanant des établissements d'enseignement et de recherche français ou étrangers, des laboratoires publics ou privés. 
1 Earthworms (Millsonia anomala, Megascolecidae) do not increase rice growth

2 through enhanced nitrogen mineralization.

3

$4 \quad$ M. Blouin, S. Barot, P. Lavelle

5

6 Laboratoire d'Ecologie des Sols Tropicaux (LEST), UMR 137, IRD, Bondy, 93143,

7 France.

8

\section{Abstract}

Earthworms have been shown to increase plant growth in $75 \%$ of the experiments that have compared plant growth in their presence and absence. However, the relative importance of the different mechanisms advanced to explain such a stimulatory effect has never been tested. In a laboratory experiment we observed increased growth of rice plants in the presence of earthworms (Millsonia anomala, Megascolecidae) and demonstrated that enhanced nitrogen release (generally considered as the principal mechanism involved in earthworm positive effect on plants) was not responsible for this result: earthworms had the same stimulatory effect on plant growth $(+20 \%)$ irrespective of whether the soil (provided with different amounts of mineral- $\mathrm{N}$ fertilizer) was either $\mathrm{N}$-limited or $\mathrm{N}$-saturated. We discuss

21 alternative explanations for the observed variations in rice production

22

23

24 Keywords: Earthworm; Mechanisms affecting plant growth; Mineralization; Nitrogen 25 gradient 
1. Introduction

29

Among the mechanisms by which earthworms modify plant growth at the individual or community levels (Scheu, 2003; Brown et al., 2004), five have been claimed to be responsible for the positive effect noted on plant production: (i) increased mineralization of soil organic matter, which increases nutrient availability (Barois et al., 1987; Knight et al., 1989; James, 1991; Curry and Byrne, 1992; Lavelle et al., 1992; Subler et al., 1997), especially for nitrogen (N), the major limiting nutrient in terrestrial ecosystems; (ii) modification of soil porosity and aggregation (Blanchart et al., 1999; Shipitalo and Le Bayon, 2004), which induces changes in water and oxygen availability for plants (Doube et al., 1997; Allaire-Leung et al., 2000); (iii) production of plant growth regulators via the stimulation of microbial activity (Frankenberger and Arshad, 1995; Muscolo et al., 1998; Nardi et al., 2002;

Quaggiotti et al., 2004); (iv) biocontrol of pests and parasites (Stephens et al., 1994;

Clapperton et al., 2001; Blouin et al., 2005); (v) stimulation of symbionts (Gange, 1993; Pedersen and Hendriksen, 1993; Furlong et al., 2002).

Enhanced $\mathrm{N}$ mineralization is the best documented mechanism and is generally thought to be the most important. However, despite 313 studies on earthworm effects on plant growth, (Brown et al., 1999; Scheu, 2003), no attempts have been made to assess the relative importance of each of these potential mechanisms (Scheu, 2003; Brown et al., 2004). Here, in a particular experimental case, we evaluate the importance of enhanced mineralization by growing rice fertilised with different levels 
51 of mineral $\mathrm{N}$. If enhanced $\mathrm{N}$ mineralization is the main mechanism involved in the

52 stimulatory effect of earthworms on plant growth, earthworm effect should be most

53 important when the $\mathrm{N}$ availability in soil is low since earthworm activities provide the

54 major amounts of mineral N. Under the same hypothesis, the stimulatory effect of

55 earthworm activities should disappear when the availability of mineral $\mathrm{N}$ in the soil is

56 high, the $\mathrm{N}$ surplus due to earthworms becoming negligible.

57

58

59

2. Materials and Methods

60

61

2.1 Experimental units

62

63

Young rice seedlings (Oryza sativa, cv. Moroberekan) were grown for three

64

months under a $600 \mu \mathrm{mol}$ photons $\mathrm{m}^{-2} \mathrm{~s}^{-1}$ artificial light source, at $28{ }^{\circ} \mathrm{C} /$ day and 24

65

${ }^{\circ} \mathrm{C} /$ night temperatures and at $75 \%+/-5 \%$ air moisture. Pots (10 cm in diameter)

66

were filled with $1 \mathrm{~kg}$ of a sandy ultisol from Lamto savannah (Ivory Coast). Nitrogen is

67

particularly limiting in the soil of the Lamto savannah : $500 \mathrm{mg} \mathrm{kg}^{-1}$ total $\mathrm{N}$ (Abbadie

68

and Lensi, 1990; Lensi et al., 1992; Gilot, 1997; Lata et al., 1999), 1.5 to 7.5 mg kg-1

69

$\mathrm{NH}_{4}{ }^{+}$and $<1 \mathrm{mg} \mathrm{kg}^{-1} \mathrm{NO}_{3}^{-}$(Martin, 1990).

70

71

2.2 Earthworms

72

73

The original soil fauna was eliminated by sieving ( $2 \mathrm{~mm}$ mesh) and freezing the

74 soil (Blouin et al., 2005). The earthworm Millsonia anomala, (Omodeo and Vaillaud,

75 1967), endemic to this region, is a large mesohumic compacting species (Blanchart 
et al., 1999), whereas the other species, Chuniodrilus zielae, (Omodeo and Vaillaud, 1967) has a somewhat larger geographical distribution and is a thin polyhumic decompacting worm (Blanchart et al., 1999). These two endogeic earthworms feed on soil organic matter; consequently, the soil was not amended with organic matter.

Three immature M. anomala $(0.85 \pm 0.20 \mathrm{~g}$ biomass $)$ and three $C$. zielae $(0.07 \pm$ $0.02 \mathrm{~g}$ ) were added in each pot according to the treatments. The population density of $M$. anomala was similar to that of natural populations, whereas that of $C$. zielae was slightly lower (Lavelle, 1978). There were four treatments: M. anomala alone (M), C. zielae alone (Ch), both species present (MCh), and a control without earthworms (C).

Some earthworms died during the experiment but the mortality of $M$. anomala and C. zielae had no significant effect on total ( $P=0.24$ and 0.14 respectively), aboveground ( $P=0.34$ and 0.12 respectively) or belowground $(P=0.14$ and 0.21 respectively) dry biomasses. The mortality was quite similar in all treatments and not related to the $\mathrm{N}$ concentrations.

91

92

\subsection{Fertilizer}

93

Soil mineral $\mathrm{N}$ content was increased by watering daily rice plants with a complete fertilizing solution in which all major mineral nutrients and oligo-elements were kept at constant concentrations except $\mathrm{N}$. Since $\mathrm{NH}_{4}{ }^{+}$is the preferred form of nitrogen taken up by rice (Fried et al., 1965; Sasakawa and Yamamoto, 1978), we modified the Hoagland-Arnon solution by replacing $\mathrm{Ca}\left(\mathrm{NO}_{3}\right)_{2}$ with $\mathrm{CaCl}_{2}$ and $\mathrm{KNO}_{3}$ with $\mathrm{NH}_{4}\left(\mathrm{SO}_{4}\right)_{2}$ and adding silicium which is necessary for many grasses. Therefore, the 
101

102

103

104

105

106

107

108

109

110

111

112

113

114

115

116

117

118

119

120

121

122 Fig. 1

123

124

125

$3950 \mu \mathrm{mol} \mathrm{I}^{-1}$; $\mathrm{Na}_{2} \mathrm{SiO}_{3}: 996 \mu \mathrm{mol} \mathrm{I}^{-1}$; Fe-EDTA (13\% of Fe): $5 \mathrm{mg} \mathrm{I}^{-1}$; Oligo-

elements : $\mathrm{H}_{3} \mathrm{BO}_{3}: 55 \mu \mathrm{mol}{ }^{-1} ; \mathrm{MnSO}_{4}: 20 \mu \mathrm{mol} \mathrm{I}^{-1} ; \mathrm{ZnSO}_{4}: 0,6 \mu \mathrm{mol}{ }^{-1} ; \mathrm{Na}_{2} \mathrm{MoO}_{4}: 0,4$ $\mu \mathrm{mol}{ }^{-1} ; \mathrm{CuSO}_{4}: 0,6 \mu \mathrm{mol} \mathrm{I}{ }^{-1} . \mathrm{NH}_{4}{ }^{+}$was supplied at five different concentrations $(0$, $25,100,400,1600 \mu_{\mathrm{mol}}^{-1}$ ) in each of the four fauna treatments, resulting altogether in 20 treatments; each was replicated 3 times.

\subsection{The $\mathrm{NH}_{4}{ }^{+}$gradient}

The test of our hypothesis requires a range of $\mathrm{N}$ concentrations, from deficient to excess $\mathrm{N}$ availability. To ensure $\mathrm{N}$-limitation for plant production in the $0 \mu \mathrm{mol} \mathrm{I}^{-1} \mathrm{NH}_{4}{ }^{+}$ treatment, we used a soil that only had $0.05 \%$ total $\mathrm{N}$ content (Martin, 1990; Abbadie and Lensi, 1990; Lensi et al., 1992; Gilot, 1997; Lata et al., 1999) and we added all the other macro- and micronutrients at adequate concentrations.

$\mathrm{NH}_{4}{ }^{+}$is known to be limiting to rice seedlings growth below $500 \mathrm{\mu mol} \mathrm{I}^{-1}$ in hydroponical conditions (Wang et al., 1993; Kirk, 2001). In our experiments, the 1600 treatment showed clear evidence of $\mathrm{NH}_{4}{ }^{+}$toxicity : excessive $\mathrm{N}$ concentration in plant tissues (fig. 1 a) and deficit in root production (Britto and Kronzucker, 2002) (fig. 1 b). This argues in favour of an alleviation of the N-limitation in the $1600 \mu \mathrm{mol}$ I-1 treatment.

\subsection{Statistical analysis}


Two complementary analyses were conducted on our data set: an ANOVA and

an ANCOVA. We checked the homogeneity of variances (Bartlett's test) and

normality of the residues (Shapiro-Wilk's test) for total, aboveground and

belowground biomasses. Residuals met the conditions of homoscedasticity $(P=$

$0.43,0.69,0.20$ respectively) and normality $(P=0.80,0.67,0.22$ respectively). With

full ANOVA model, the effects of nitrogen, $M$. anomala, $C$. zielae and the interactions

between these factors were tested (Table 1). In this analysis, nitrogen was

considered as a discrete factor. To visualize our results more easily, an ANCOVA

was conducted considering nitrogen as a continuous variable. The effect of nitrogen significant factor(s) of the ANOVA (earthworm species) may affect significantly some of the parameters of the polynom, modifying the regression equation as compared with the control one.

\section{Results}

As expected, the ANOVA showed that the $\mathrm{N}$ gradient had a significant effect on plant dry total and above-ground biomasses (Table 1). Comparisons between means

146 (Tukey's test for multiple comparisons) showed that total and above-ground

147 biomasses were not significantly different from the $0 \mu \mathrm{mol} \mathrm{I}^{-1}$ to the $100 \mu \mathrm{mol} \mathrm{I}^{-1}$ 148 treatments, but increased significantly from the 100 to the $400 \mathrm{~mol} \mathrm{I}^{-1}$ treatments 149 (respectively +18 and $19.5 \%$ ) and from the 400 to the $1600 \mu \mathrm{mol} \mathrm{I}^{-1}$ treatments 150 (respectively +19 and $31 \%$ ), showing that plant growth was $\mathrm{N}$-limited at the lowest 
$151 \mathrm{NH}_{4}{ }^{+}$concentrations. No significant effect of the $\mathrm{N}$ gradient was observed on below-

152 ground biomass (Fig. 1c). M. anomala had a significant effect on total, above-ground 153 and below-ground biomasses. However, its interaction with the $\mathrm{N}$ concentration was

154 not significant (Table 1). The positive effect of $M$. anomala on plant production did not

155 depend on the $\mathrm{N}$ concentration. Nor $\mathrm{C}$. zielae neither its interactions with the $\mathrm{N}$

156 concentration or M. anomala had a significant effect on plant production (Table 1).

157

158 Table 1

159

As C. zielae had no significant effect in the ANOVA, we realize the ANCOVA to

161 test the effect of $M$. anomala, independently of the presence of $C$. zielae : control (C)

162 and C. zielae treatments, and M. anomala and M. anomala-C. zielae treatments 163 respectively were pooled together.

164

Table 2

166

The relationship between plant total and above-ground biomasses with the $\mathrm{N}$ gradient fitted on a second order polynom $\left(y=a+b x+c x^{2}\right)$ (Table 2). Below-ground biomass did not vary significantly along the $\mathrm{N}$-gradient $(\mathrm{y}=\mathrm{a})$. For total and aboveground biomasses $M$. anomala had a significant positive effect on the parameter a, 171 but not on b or c (Table 2; Fig. 2a and 2b). M. anomala also had a significant effect 172 on the parameter a for below-ground biomass (Fig. 2c). Taken together, M. anomala 173 had a constant positive effect on plant production along the $\mathrm{N}$-gradient : $+20,16$ and $17435 \%$ for the total, above-ground and below-ground biomasses respectively. 
176 Fig. 2

177

178

\section{Discussion}

179

180

We postulated that if enhanced $\mathrm{N}$ mineralization is an important mechanism

181 involved in the positive effect of earthworms on plant growth, earthworms should

182 have a positive effect in a $\mathrm{N}$-limited environment but not in a $\mathrm{N}$-saturated

183 environment, where the enhanced mineralization of $\mathrm{N}$ is negligible. Both an ANOVA,

184 taking into account the presence of $C$. zielae, and an ANCOVA, where the presence

185 of M. anomala was considered independently of the presence of C. zielae, showed

186 that the effect of $M$. anomala was constant whatever the $\mathrm{N}$ concentrations. Thus, we

187 can reject the hypothesis that the main effect of $M$. anomala on plant production was

188 due to increased $\mathrm{N}$ mineralization. If $M$. anomala would increase plant production

189 through an enhanced mineralization of other nutrients (such as $\mathrm{P}, \mathrm{K} \ldots$ etc), this

190 would have produced no effect on plant in a N-limited environment, but an increase

191 in plant growth in situations where plant is no longer limited by N. This was not

192 observed in our experiment (Fig. 2) and we therefore reject this hypothesis.

193

194 In contrast to M. anomala, C. zielae had no significant effect on plant biomass.

195 Only a slight positive effect of $C$. zielae on root biomass had been observed

196 previously (Derouard et al., 1997). In our experiment the soil was probably not

197 compacted enough to allow the decompacting effect of $C$. zielae to influence plant

198 growth significantly. 
The increase in plant aboveground biomass simultaneously with the absence of

201 an increase in belowground biomass along the $\mathrm{N}$ gradient indicates that the rice 202 plants allocated less resource to the root system as $\mathrm{N}$ availability increased 203 (Thornley, 1972; Wilson, 1988; Andrews, 1993). In contrast, the presence of $M$. 204 anomala increased both above- and belowground biomasses. Two separate 205 mechanisms were probably responsible for the differing plant responses to the $\mathrm{N}$ 206 gradient and to the presence or M. anomala (see below).

207 Since M. anomala effect was constant over the N-gradient, our experiment does 208 not support the widespread belief that enhanced mineralization by earthworms is the 209 main causal mechanism to explain the increased rice growth in presence of $M$.

210 anomala. Nevertheless, this mechanism could be important in other plant-earthworm 211 associations. Moreover, our experiment allows the hypothesis of an enhanced 212 nitrogen mineralization to be excluded at high levels of $\mathrm{N}$, but not at low levels: 213 different mechanisms could in fact be involved at different $\mathrm{N}$ concentrations. The 214 mechanism(s) responsible for the positive effect on plant growth at high $\mathrm{N}$ 215 concentration cannot be clearly identified from our results. Nevertheless, an 216 improvement of soil water or oxygen availabilities by $M$. anomala can probably be 217 ruled out because soil was maintained at an optimal value of $80 \%$ field capacity by 218 daily watering. Control of specialist parasites or the stimulation of symbionts likely did 219 not occur in our experiment because the soil originated from a non-cultivated 220 savannah with no crop-specific parasites or symbionts, and the original soil fauna 221 had been eliminated. We cannot, however, discard the hypothesis that microbial 222 generalist parasites or symbionts may have been controlled or stimulated by $M$. 223 anomala. This leaves the production of plant growth regulators (Frankenberger and 224 Arshad, 1995; Muscolo et al., 1998; Nardi et al., 2002; Quaggiotti et al., 2004) as the 
225 probable explanation of the stimulatory effect of $M$. anomala on rice in our 226 experiment. The possibility and the detailed mechanisms of the control of plant 227 physiology via phytohormones secreted into soils by the bacteria associated with 228 earthworms activities should be studied thoroughly.

229

230

\section{Acknowledgements}

232

233

We thank Jérome Tondoh and Souleymane Konaté for supplying soil and

234 animals, Anne Pando and Jocelyne Roman for their technical help, Daniel Chessel

235 for his advice on statistical analyses and Aram Marks for his help in English

236 improvement.

237

238

239

240

\section{References}

242

243 Abbadie, L. and Lensi, R., 1990. Carbon and nitrogen mineralization and

244 denitrification in a humid savanna of West Africa (Lamto, Côte d'Ivoire). Acta

245 Oecologica 11, 717-728.

246 Allaire-Leung, S.E., Gupta, S.C. and Moncrief, J.F., 2000. Water and solute

247 movement in soil as influenced by macropore characteristics. 1.Macropore

248 continuity. Journal of Contaminant Hydrology 41, 283-301. 
Andrews, M., 1993. Nitrogen effect on the partitionning of dry matter between shoot and root of higher plants. Current Topics in Plant Physiology 1, 119-126.

251 Barois, I., Verdier, B., Kaiser, P., Mariotti, A., Rangel, P. and Lavelle, P., 1987. Influence of the tropical earthworm Pontoscolex corethrurus (Glossoscolecidæ) on the fixation and mineralization of nitrogen. In: Bonvicini, A.M. and Omodeo, P. (Eds), On Earthworms. Mucchi, Bologna, Italy, pp. 151-158.

Blanchart, E., Albrecht, A., Alegre, J., Duboisset, A., Gilot, C., Pashanasi, B., Lavelle, P. and Brussaard, L., 1999. Effects of earthworms on soil structure and physical properties. In: Lavelle, P., Brussaard, L. and Hendrix, P. (Eds), Earthworm management in tropical agroecosystems. CAB International, Wallingford, pp. $149-172$.

Blouin, M., Zuily-Fodil, Y., Pham-Thi, A.T., Laffray, D., Reversat, G., Pando, A., 261 Tondoh, J. and Lavelle, P., 2005. Belowground organism activities affect plant aboveground phenotype, inducing plant tolerance to parasites. Ecology Letters 8, 202-208.

264 Britto, D.T. and Kronzucker, H.J., 2002. $\mathrm{NH}_{4}{ }^{+}$toxicity in higher plants: a critical 265 review. Journal of Plant Physiology 159, 567-584.

266 Brown, G.G., Edwards, C.A. and Brussaard, L., 2004. How earthworms affect plant growth: burrowing into the mechanisms. In: Edwards, C.A. (Eds), Earthworm ecology. CRC Press, Boca Raton, USA, pp. 13-49.

269 Brown, G.G., Pashanasi, B., Villenave, C., Patron, J.C., Senapati, B.K., Giri, S., 270 Barois, I., Lavelle, P., Blanchart, E., Blakemore, R.J., Spain, A.V. and Boyer, J., 1999. Effects of earthworms on plant production in the tropics. In: Lavelle, P., Brussaard, L. and Hendrix, P. (Eds), The management of earthworms in tropical agroecosystems. CAB International, Wallingford, pp. 87-148. 
274 Clapperton, M.J., Lee, N.O., Binet, F. and Conner, R.L., 2001. Earthworms indirectly 275 reduce the effects of take-all (Gaeumannomyces graminis var. tritici) on soft white spring wheat (Triticum aestivum cv. Fielder). Soil Biology and Biochemistry 33, 1531-1538.

278 Curry, J.P. and Byrne, D., 1992. The role of earthworms in straw decomposition and nitrogen turnover in arable land in Ireland. Soil Biology and Biochemistry 24, 1409-1412.

281 Derouard, L., Tondoh, J., Vilcosqui, L. and Lavelle, P., 1997. Effects of earthworm introduction on soil processes and plant growth. Soil Biology and Biochemistry 29, $541-545$.

284 Doube, B.M., Williams, P.M.L. and Willmott, P.J., 1997. The influence of two species of earthworm (Aporrectodea trapezoides and Aporrectoedea rosea) on the growth of wheat, barley and faba beans in three soil types in the greenhouse. Soil Biology and Biochemistry 29, 503-509.

288 Frankenberger, W.T. and Arshad, M., 1995. Phytohormones in soils : Microbial 289 production and function. Marcel Dekker, New York, 503 pp.

290 Fried, M.F., Zsoldos, F., Vose, P.B. and Shatokhin, I.L., 1965. Characterizing the $\mathrm{NO}_{3}{ }^{-}$and $\mathrm{NH}_{4}{ }^{+}$uptake process of rice roots by use of ${ }^{15} \mathrm{~N}$ labelled $\mathrm{NH}_{4} \mathrm{NO}_{3}$. Physiologia Plantarum 18, 313-320.

293 Furlong, M.A., Singleton, D.R., Coleman, D.C. and Whitman, W.B., 2002. Molecular 294 and culture-based analyses of prokaryotic communities from an agricultural soil 295 and the burrows and casts of the earthworm Lumbricus rubellus. Applied and 296 Environmental Microbiology 68, 1265-1279.

297 Gange, A.C., 1993. Translocation of mycorrhizal fungi by earthworms during early 298 succession. Soil Biology and Biochemistry 25, 1021-1026. 
299 Gilot, C., 1997. Effects of a tropical geophageous earthworm, Millsonia anomala 300 (Megascolecidae), on soil characteristics and production of a yam crop in Ivory $301 \quad$ Coast. Soil Biology and Biochemistry 29, 353-359.

302 James, S.W., 1991. Soil nitrogen, phosphorus, and organic matter processing by 303 earthworms in tallgrass prairie. Ecology 72, 2101-2109.

304 Kirk, G.J.D., 2001. Plant-mediated processes to acquire nutrients: nitrogen uptake by 305 rice plants. Plant and Soil 232, 129-134.

306 Knight, D., Elliott, P.W. and Anderson, J.M., 1989. Effects of earthworms upon 307 transformations and movement of nitrogen from organic matter applied to 308 agricultural soils. In: Hansen, J.A. and Henriksen, K. (Eds), Nitrogen in organic 309 wastes applied to soils. Academic Press, London, pp. 59-80.

310 Lata, J.C., Durand, J., Lensi, R. and Abbadie, L., 1999. Stable coexistence of 311 contrasted nitrification statuses in a wet tropical savanna ecosystem. Functional 312 Ecology 13, 762-768.

313 Lavelle, P., 1978. Les vers de terre de la savane de Lamto (Côte d'Ivoire):

314 peuplements, populations et fonctions dans l'écosystème. Thèse d'état, 315 Laboratoire de zoologie de l'ENS, Paris 6, Paris, pp.

316 Lavelle, P., Melendez, G., Pashanasi, B. and Schaefer, R., 1992. Nitrogen

317 mineralization and reorganization in casts of the geophagous tropical earthworm 318 Pontoscolex corethrurus (Glossoscolecidae). Biology and Fertility of Soils 14, 4931953.

320 Lensi, R., Domenach, A.M. and Abbadie, L., 1992. Field study of nitrification and 321 denitrification in a wet savanna of West Africa (Lamto, Côte d'Ivoire). Plant and 322 Soil $147,107-113$. 
323 Martin, S., 1990. Modélisation de la dynamique et du rôle d'une population de vers

324 de terre Millsonia anomala dans les savanes humides de Côte d'Ivoire. Université 325 Paris 6, Paris, $206 \mathrm{pp}$.

326 Muscolo, A., Cutrupi, S. and Nardi, S., 1998. IAA detection in humic substances. Soil 327 Biology and Biochemistry 30, 1199-1201.

328 Nardi, S., Pizzeghello, D., Muscolo, A. and Vianello, A., 2002. Physiological effects of 329 humic substances on higher plants. Soil Biology and Biochemistry 34, 1527-1536. 330 Omodeo, P. and Vaillaud, M., 1967. Les Oligochètes de la savane de Gpakobo en 331 Côte d'Ivoire. Bulletin de l'Institut Français d'Afrique Noire 29, 925-944.

332 Pedersen, J.C. and Hendriksen, N.B., 1993. Effect of passage through the intestinal 333 tract of detritivore earthworms (Lumbricus spp.) on the number of selected Gram334 negative and total bacteria. Biology and Fertility of Soils 16, 227-232.

335 Quaggiotti, S., Ruperti, B., Pizzeghello, D., Francioso, O., Tugnoli, V. and Nardi, S., 336 2004. Effect of low molecular size humic substances on nitrate uptake and expression of genes involved in nitrate transport in maize (Zea mays L.). Journal

339 Sasakawa, H. and Yamamoto, Y., 1978. Comparison of the uptake of nitrate and ammonium by rice seedlings. Influences of light, temperature, oxygen concentration, exogenous sucrose and metabolic inhibitors. Plant Physiology 62, 649-669.

Scheu, S., 2003. Effects of earthworms on plant growth: patterns and perspectives. Pedobiologia 47, 846-856.

Shipitalo, M.J. and Le Bayon, R.C., 2004. Quantifying the effects of earthworms on $347 \quad$ Press, Boca Raton, pp. 441. 
348 Stephens, P.M., Davoren, C.W., Doube, B.M. and Ryder, M.H., 1994. Ability of the 349 lumbricid earthworms Aporrectodea rosea and Aporrectodea trapezoides to 350 reduce the severity of take-all under greenhouse and field conditions. Soil Biology $351 \quad$ and Biochemistry 26, 1291-1297.

352 Subler, S., Baranski, C.M. and Edwards, C.A., 1997. Earthworm additions increased 353 short-term nitrogen availability and leaching in two grain-crop agroecosystems.

354 Soil Biology and Biochemistry 29, 413-421.

355 Thornley, J.H.M., 1972. A balanced quantitative model for root:shoot ratios in 356 vegetative plants. Annals of Botany 68, 211-216.

357 Wang, M.Y., Siddiqi, M.Y., Ruth, T.J. and Glass, A.D.M., 1993. Ammonium uptake by 358 rice roots. II. Kinetics of ${ }^{13} \mathrm{NH}_{4}{ }^{+}$influx across the plasmalemma. Plant Physiology $359 \quad 103,1259-1267$.

360 Wilson, J.B., 1988. A review of evidence on the control of shoot:root ratio, in relation 361 to models. Annals of Botany 61, 433-449. 
364 Factors affecting total, shoot and root biomasses from a three-way ANOVA

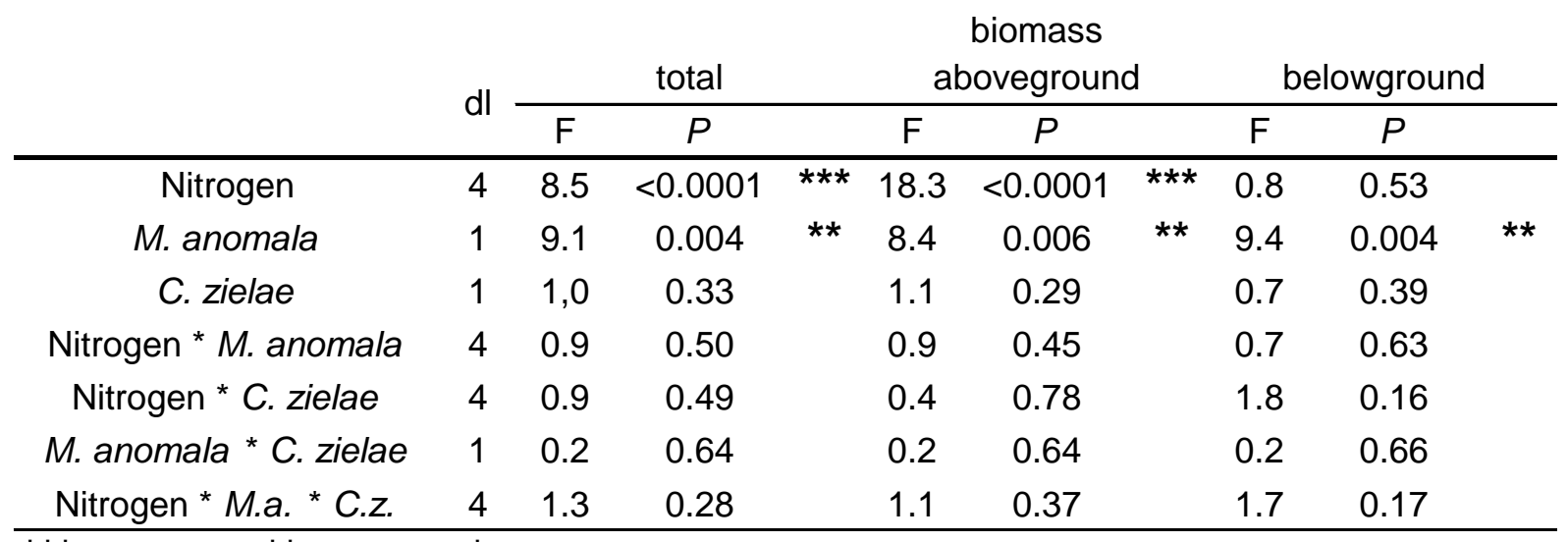

366

$367 \quad$ Table 2

368 Polynomial equations determined with the ANCOVA

\begin{tabular}{|c|c|c|c|c|c|c|c|c|c|c|}
\hline \multirow{2}{*}{$\begin{array}{c}\text { model: } \\
\mathrm{y}=\underset{\mathrm{a}+\mathrm{bN}+\mathrm{cN}^{2}+\mathrm{dN}^{3}}{\text { coefficients of }}\end{array}$} & \multirow{2}{*}{$\mathrm{dl}$} & \multicolumn{6}{|c|}{$\begin{array}{c}\text { biomass } \\
\text { aboveground }\end{array}$} & \multicolumn{3}{|c|}{ belowground } \\
\hline & & $\mathrm{F}$ & $P$ & & $\mathrm{~F}$ & $P$ & & $\mathrm{~F}$ & $P$ & \\
\hline$N(b)$ & 1 & 18.0 & $<0.0001$ & 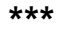 & 42.0 & $<0.0001$ & *** & 0.2 & 0.68 & \\
\hline $\mathrm{N}^{2}(\mathrm{c})$ & 1 & 14.5 & 0.0004 & *** & 33.1 & $<0.0001$ & 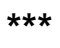 & 0.2 & 0.64 & \\
\hline$N^{3}(d)$ & 1 & 0.03 & 0.87 & & 0.98 & 0.33 & & 1.3 & 0.25 & \\
\hline M. anomala (a) & 4 & 8.7 & 0.005 & ** & 8.27 & 0.006 & ** & 8.5 & 0.005 & $\star \star \star$ \\
\hline $\mathrm{N}$ * M. anomala (b) & 4 & 0.3 & 0.57 & & 0.26 & 0.61 & & 0.4 & 0.53 & \\
\hline $\mathrm{N}^{2} *$ M. anomala $(\mathrm{c})$ & 1 & 0.001 & 0.98 & & 0.0004 & 0.99 & & 0.01 & 0.91 & \\
\hline $\mathrm{N}^{3 *}$ M. anomala $(\mathrm{d})$ & 1 & 0.8 & 0.37 & & 1.19 & 0.28 & & 0.3 & 0.58 & \\
\hline
\end{tabular}


370 Fig. 1

371 Rice responses to the $\mathrm{N}$-gradient according to the presence of earthworms. (a)

372 Percentage of $\mathrm{N}$ in plants. (b) Shoot:root ratio of plants. Without lines: control without

373 fauna; Horizontal lines: M. anomala; Vertical lines: C. zielae; Horizontal and vertical

374 lines: C. zielae and M. anomala. Means \pm s.e., $\mathrm{n}=60$.

375

$376 \quad$ Fig. 2

377 Response of plant dry biomasses to earthworms along a nitrogen gradient. (a)

378 Total biomass, (b) Shoot biomass, (c) Root biomass. Nitrogen concentration was

379 expressed as $\log (1+[\mathrm{N}])$ for more clarity. The polynomial equation of curves was

380 obtained by regression analysis, where the significance of the different coefficients

381 was tested. O: control without fauna; $\Delta:$ C. zielae; +: M. anomala; x: C. zielae and $M$.

382 anomala. The different regression lines are represented only for the significant

383 factors; solid line: without M. anomala, dashed line: with M. anomala. $\mathrm{n}=60$.

384

385 